\title{
The Influence of Cash Flow, Leverage and Profitability on Investment Decisions in Financial Distress Companies (All Companies Listed on Indonesia Stock Exchange of 2017-2019)
}

\author{
Sonia Nanda Aprilia Putri \\ STIE Bank BPD Jateng \\ Jl. Soekarno Hatta No. 88, Semarang, Jawa Tengah \\ 59160 Semarang, Jawa Tengah, Indonesia \\ soniananda.ap23@gmail.com
}

\author{
Siti Puryandani \\ STIE Bank BPD Jateng \\ Jl. Soekarno Hatta No. 88, Semarang, Jawa Tengah \\ 59160 Semarang, Jawa Tengah, Indonesia \\ sitipuryandani@gmail.com
}

\begin{abstract}
This study aims to analyze the effect of cash flow, leverage, and profitability on investment decisions in companies experiencing financial distress. The independent variable $(X)$ of this study is cash flow, leverage, and research profitability. The investment decision is the dependent variable (Y). The sampling method used in this study is the Altman Z"Score method and purposive sampling. The study population came from all companies listed on the Indonesia Stock Exchange (IDX) during the 2017-2019 period, obtained 699 companies. The data analysis technique used descriptive statistical analysis; classical assumption test: normality test, multicollinearity test, heteroscedasticity test, autocorrelation test; multiple linear regression analysis; Hypothesis testing: Ttest, -F test, the test of the coefficient of determination. The results of this study are cash flow and leverage do not affect the investment decisions of companies experiencing financial distress. Profitability has a positive effect on the investment decisions of companies experiencing financial distress.
\end{abstract}

Keywords: Cash Flow, Leverage, Profitability, Investment Decisions, Financial distress

\section{INTRODUCTION}

The influence of the development of the capital market in Indonesia has a significant impact on the economy. One of the activities is an investment which invested in the long term company's assets. Companies make investments expect profits and future survival. The impact of the development of the capital market in this economic sector has resulted in intense competition between companies from various sectors. Companies need to develop and advance their business. In fact any decision to invest implies assuming a certain degree of risk [17]. The company's financial condition describes the company's performance. If the financial condition is good, it can be said that the company is successful in maintaining its sustainability. However, a company with a bad financial condition means that the company is unable to compete in the market. Companies can experience losses to experience financial distress. If this condition is not handled properly, the company can go bankrupt. In 2019, data from the Indonesia Stock Exchange (IDX) as of December 2019, recorded many 27 firms are vulnerable to bankruptcy. The role of managers in conditions of financial difficulty is very important, including in making investment decisions. Managers need to make various considerations both in terms of risks, returns, and the ability of the company when making investments so that the benefits in the future can be felt. [14] Factors that receive attention in company investment decisions include cash flow, capital structure, liquidity, debt policy, profitability, sales growth, and so on. In companies that do not experience financial difficulties or can compete between companies, they can make decisions to invest because of low-risk considerations with large returns. However, it is different for companies that experience financial distress, these companies do not behave in the same way [1]. Financial distress companies have different behaviors in making investment decisions. Companies with financial difficulties are sensitive to cash flow. Cash inflow less than outflow can influence investment decisions. This is because there are no funds to invest. Companies with financial difficulties have large leverage and show that the risks they bear are also large. Companies will tend to reduce this risk by not increasing investment. In addition to low cash flow and high leverage, financial distress firms have low profitability. The productivity of using assets is not optimal so that the profit earned is small. Low profit means that the company's internal funds are also low so that the availability of funds for investment is also low. These variables will be raised in this study whether there is an influence between cash flow, leverage, and profitability on investment decisions in financial distress companies.

\section{LITERATURE REVIEW}

A. Modigliani and Miller's Irrelevance Theory

The theory developed by Modigliani and Miller (MM) in 1958 explained that there is no relationship between capital structure (increasing debt or equity) and firm value if there is no tax. MM developed his theory in 1963 by including elements of income tax. This assumption states that the existence of a tax element on income can increase firm value. This assumption implies that companies prefer to use debt to fund the company.

B. Trade-Off Theory 
According to [5] the trade-off theory explains that there is a relationship between capital structure and firm value, there is an optimal level of leverage. In this theory, companies can consider the use of debt to an optimal point with bankruptcy and agency costs to increase firm value [12]. Debt ratio that is above the optimal point, the company value will decrease. This occurs because of the increasing use of debt affects the conflict of interest between creditors and owners. It is clear that the more the debt increases, the benefits of the debt no longer cover these costs.

C. Pecking Order Theory

This theory explains the order in which funds are used to finance an investment or the company's operational activities (Myres, 1984). According to the pecking order theory, funds that are considered cheap are internal funds because the company does not have responsibility for issuance costs [15]. Internal funds can be in the form of funds originating from company owners, retained profit retained earnings, and accumulated depreciation surplus funds. The order in which funds are used according to this theory is to use internal funds first if there is not enough transfer to external funds. External funds are funds originating from the bank, sale of shares, insurers, and other creditors.

\section{Signaling Theory}

According to Miller \& Rock (1985), in this theory, there is an imbalance of information between managers and investors about how management sees the future of corporate investment. This theory assumes managers have better information and knowledge than investors about the real state of the company. The signaling theory states that issuance of shares sends a bad signal to the market while debt decisions send a positive signal to the market [15].

\section{E. Investment Decision}

The investment decision is a decision to use company funds to invest. The financial manager in this case has a big responsibility to allocate company funds properly. The decision to use funds for investment is the same as capital expenditure. Capital expenditures are forecasted based on the investment opportunities and the economic condition of the firm at the time of the forecast [2]. With capital expenditures, it is hoped that the company can get benefits in the long term.

\section{F. Cash Flow}

The cash flow statement is a financial report that contains information about the company's cash inflows and outflows. Cash inflows are obtained from transactions from main operating activities, extraordinary activities, side investment activities, and financing with debt and equity. Cash outflows are used for transactions for the use of working capital, company investment, payment of interest, dividends, and debt. Financial distress is characterized by a negative cumulative income for at least several consecutive years, losses and poor performance [3].

\section{G. Leverage}

Leverage is the level of debt used to fund company assets [6]. Companies that have a series of debts, can add interest costs in their repayment payments. But deficient self-control leads people to overextend themselves into "debt traps" [18]. The amount of debt a company has can affect the risk of financial distress.

H. Profitability

All companies have a goal of getting a large profit or profit. This is measured by the company's profitability. Profitability is capital expenditures are forecasted based on the investment opportunities and the economic condition of the firm at the time of the forecast [4]. These resources can be in the form of sales activities, total assets, and own capital.In predicting financial distress, the firms with high ptofitability face fewer chances of financial distress [13].

I. Hypothesis :

H1: Cash flow has a positive effect on investment decisions for companies experiencing financial distress.

$\mathrm{H} 2$ : Leveragehas a negative effect on investment decisions for companies experiencing financial distress.

H3: Profitability has a positive effect on investment decisions for companies experiencing financial distress.

\section{METHODOLOGY}

The population of this research is all 699 companies listed on the Indonesia Stock Exchange (BEI). The sampling technique used was the purposive sampling method and Altman Z "-Score. There are 4 criteria in the purposive sampling method and resulted in 257 companies that will be detected by the Altman $Z$ "-Score method. Altman Z "-Score equation of this research is $Z "=6.56 \mathrm{X} 1$ $+3.26 \mathrm{X} 2+6.72 \mathrm{X} 3+1.05 \mathrm{X} 4$ with the result of the equation value if the value of $\mathrm{Z} "<1.1$ then the company is experiencing financial distress if the value of $1.1<Z "<2.6$ then the calculated company is located in the gray zone. If the value of $Z^{\prime \prime}>2.6$ then the calculated company does not experience financial distress. The results of the calculation of the $\mathrm{Z}$ "-Score equation, resulted in 75 companies that were detected to experience financial distress and became the sample of this study.

The proxy for investment decision variables is capital expenditure. The proxy for cash flow is the operating cash flow divided by total assets. The proxy for leverage is the Debt to Assets Ratio (DAR). The proxy for profitability is the return on assets (ROA). The data analysis technique used to solve this research problem is descriptive statistical analysis, classical assumption test, multiple linear regression analysis, the goodness of fit test, and hypothesis testing using the SPSS (Statistical Package for Social Science) 25 computer program. The classic assumption test consists of 
the normality test, multicollinearity test, autocorrelation test, and heteroscedasticity test. The goodness of fit test consists of the fit model test and the coefficient of determination test. Hypothesis testing consists of the T-test.

\section{RESULTS AND DISCUSSION}

\section{A. Descriptive Statistic Analysis}

The results of descriptive statistics show the lowest value of the cash flow variable for companies experiencing financial distress for the 2017-2019 period of -0.3275645. The highest value of the current variable is 0.94450495 . Cash flows have an average value of 0.2252669 and a standard deviation of 0.2579585 . This average value shows that most of the sample companies have low cash flows because they are close to the lowest value. A standard deviation value that is higher than the average value indicates that the data is relatively heterogeneous.

The results of descriptive statistics show the lowest value of the leverage variable as measured by the Debt to Assets Ratio (DAR) of companies experiencing financial distress for the 2017-2019 period of 0.1804532. The highest value of the leverage variable is 1.144083 . Leverage has an average value of 0.6583215 and a standard deviation of 0.1993787 . This average value shows that most of the sample companies have high leverage because they are close to the highest value. The standard deviation value that is lower than the average value indicates that the data is relatively homogeneous.

The results of descriptive statistics show the lowest value of the profitability variable as measured by the Return on Assets (ROA) of companies experiencing financial distress for the 2017-2019 period of -0.14464842. The highest value of the profitability variable is .09138337. Profitability has an average value of -0.017397 and a standard deviation of 0.0501876 . This average value shows that most of the sample companies have low profitability because they are close to the lowest value. A standard deviation value that is higher than the average value indicates that the data is relatively heterogeneous.

The results of descriptive statistics show the lowest value of the investment decision variable for companies experiencing financial distress for the 2017-2019 period of 0.2067906 . The highest value of the investment decision variable is 0.20015824 . The investment decision has an average value of -0.0017525 and a standard deviation of 0.0826736 . This average value shows that most of the sample companies have low investment decisions because they are close to the lowest value. A standard deviation value that is higher than the average value indicates that the data is relatively heterogeneous.

\section{B. Normality Test}

In this study, the original data used were 225 data. However, in the normality test, the results show a sig value of 0.000 below 0.05 , which means that the data is not normally distributed. Then the outlier data test was carried out by eliminating 105 extreme value data, so it can be concluded, this study uses 120 data that can be tested with data that is normally distributed. From the results of the Kolmogorov-Smirnov One-Sample test after the removal of outliers, the Asymp Sig value is obtained. (2-tailed) of 0.079. Asymp Value Sig. (2-tailed) 0.079 is greater than the significance level of the normality test, namely 0.05 . Asymp Value Sig. (2-tailed) greater than 0.05 means that the research data is normally distributed.

\section{Multicollinearity Test}

The multicollinearity test results obtained the tolerance value of each independent variable, namely: the tolerance value for cash flow is 0.815 ; leverage is 0.827 ; profitability is 0.949 . The VIF value for cash flows is 1.227 ; the VIF value for leverage is 1.209 ; the VIF value for profitability is 1.054. So it can be concluded that the multicollinearity test results in this study resulted in the independent variables having a tolerance value $>0.1$ and a VIF value $<10$. This indicates that there is no multicollinearity or no correlation between the independent variables in the regression model.

\section{Heteroscedasticity Test}

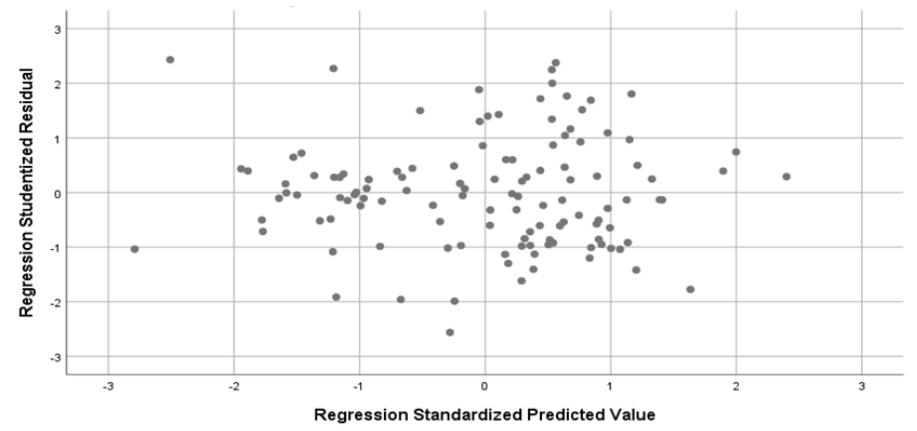

Figure 4.1 Heteroscedasticity Test Result

So it can be concluded that there is no heteroscedasticity in the regression model because the Scatterplot forms a graph of random patterned points that spread above and below the number 0 and the Y-axis.

E. Autocorrelation Test

\begin{tabular}{|c|c|c|c|c|c|}
\hline Model & $\mathrm{R}$ & $\begin{array}{c}\mathrm{R} \\
\text { Square }\end{array}$ & $\begin{array}{c}\text { Adjusted } \\
\text { R Square }\end{array}$ & $\begin{array}{c}\text { Std. Error of } \\
\text { the Estimate }\end{array}$ & $\begin{array}{c}\text { Durbin- } \\
\text { Watson }\end{array}$ \\
\hline 1 & 0.330 & 0.109 & 0.086 & 0.790 & 1.564 \\
\hline
\end{tabular}

Table 4.1 Autocorrelation Test Result

The autocorrelation test of this study was obtained from the Durbin Watson (DW) value of 1.564. The results of the autocorrelation test resulted in a DW value between -2 to +2 , this means that in this study there was no autocorrelation.

\section{F. Multiple Linear Regression Analysis}

The multiple linear regression equation is as follows:

$$
\mathrm{KI}=0,014-0,040 \mathrm{CF}+0,004 \mathrm{DAR}+0,548 \mathrm{ROA}+\mathrm{e}
$$


- The KI constant is $0.014 \&$ is positive or unidirectional. If the independent variable is zero or constant, the change in the dependent variable is 0.014 .

- $\mathrm{CF}$ variable coefficient $(\mathrm{X} 1)$ is $-0.040 \&$ is negative. An increase in the cash flow variable by one unit decreases the investment decision variable by -0.040 units.

- DAR variable coefficient (X2) is $0.004 \&$ is positive. An increase in the leverage variable by one unit increases the investment decision variable by 0.004 units.

- The variable coefficient of ROA (X3) is $0.548 \&$ is positive. The increase in the one-unit profitability variable led to an increase in the investment decision variable, namely 0.548 units.

G. Model Fit Test (F Test)

\begin{tabular}{|c|c|c|c|c|c|c|}
\hline \multicolumn{2}{|l|}{ Model } & $\begin{array}{c}\text { Sum of } \\
\text { Squares }\end{array}$ & df & $\begin{array}{c}\text { Mean } \\
\text { Square }\end{array}$ & F & Sig \\
\hline \multirow{2}{*}{1} & Regression & 0.089 & 3 & 0.030 & 4.737 & 0.004 \\
\cline { 2 - 7 } & Residual & 0.725 & 116 & 0.006 & & \\
\cline { 2 - 7 } & Total & 0.813 & 119 & & & \\
\hline
\end{tabular}

Table 4.2 Model Fit Test (F Test) Result

Based on Table 4.6, the calculation results show that the significance value of this study is 0.004 . The significance value is $0.004<0.05$, the independent variable as a whole affects the dependent variable.

\section{H. Coefficient of Determination}

This concludes that the influence of the independent variable $(\mathrm{X})$, namely cash flow proxied by cash flow $(\mathrm{CF})$, leverage proxied by DAR, and profitability proxied by ROA in explaining variations in the dependent variable (Y), namely investment decisions proxied by $\mathrm{KI}$ of $8.6 \%$ and the remaining $91.4 \%$ is explained by other variables outside the equation. It can also be interpreted that the independent variables of this study have a low or limited ability to explain the variation in the dependent variable.

I. T-Test

\begin{tabular}{|c|c|c|c|c|c|c|}
\hline \multicolumn{2}{|c|}{ Model } & B & T & Sig & Tolarance & VIF \\
\hline 1 & (Constant) & 0.014 & 0.468 & 0.641 & & \\
\hline & Cash Flow & -0.040 & -1.291 & 0.199 & 0.815 & 1.227 \\
\hline & Leverage & 0.004 & 0.096 & 0.923 & 0.827 & 1.209 \\
\hline & Profitability & 0.548 & 3.697 & 0.000 & 0.949 & 1.054 \\
\hline
\end{tabular}

Table 4.3 T-Test Result

- The results of the T-test cash flow have a significance value of 0.199 . The significance value of $0.199>0.05$ indicates that cash flow has no effect on investment decisions, so the first hypothesis is rejected.

- The results of the T-test leverage the significance value of 0.923 . The significance value of $0.923>0.05$ indicates that leverage has no effect on investment decisions, so the second hypothesis is rejected.
- T-test results of profitability have a significance value of 0.000 . The significance value of $0.000<0.05$ indicates that profitability has an effect on investment decisions, so the third hypothesis is accepted.

\section{J. Hypothesis Testing Results}

1. The first hypothesis (H1) states that cash flow has a positive effect on investment decisions in companies experiencing financial distress. Obtained a significance value of 0.199 . The significance value of $0.199>0.05$ indicates that cash flow has no effect on investment decisions, so the first hypothesis is rejected (rejects $\mathrm{H} 1$ ). The results of this test mean that the amount of operating cash flow of the company does not significantly influence the investment decisions of companies experiencing financial distress. Companies that experience financial distress in this study have low operating cash flows. According to the pecking order theory, the order of the use of funds in financing an investment or company operational activities begins with internal funds, namely the availability of cash. In this case, the company's internal funds with low cash flow as the first alternative are not a consideration for managers to decide whether to invest or not. This can be caused by other considerations for investment decisions is investment opportunities. Investment opportunities are opportunities to realize more benefits through investment. Investment opportunity choices (IOS) are expected to produce greater returns in the future indicated by a positive NPV. The managers of financial distress will take advantage of these investment opportunities with the right considerations and calculations. This is closely related to the condition of the company whether it can recover or suffer more and more losses. The results of this study support the research of [7], [8] that there is no effect of cash flow on investment decisions. The non-impact of cash flows indicates that the company does not react or does not pay special attention as a consideration for making investment decisions.

2. The second hypothesis (H2) states that leverage has a negative effect on investment decisions in companies experiencing financial distress. Obtained a significance value of 0.923 . The significance value of $0.923>0.05$ indicates that leverage has no effect on investment decisions, so the second hypothesis is rejected (rejects $\mathrm{H} 2$ ). The results of this test imply that the amount of corporate leverage does not significantly influence the investment decisions of companies experiencing financial distress. Companies that experience financial distress in this study have high leverage. The trade-off theory explains that there is a relationship between capital structure and firm value, there is an optimal level of leverage. The value of companies experiencing 
financial distress has a low value. In this theory, companies can consider the use of debt to an optimal point with bankruptcy and agency costs to increase firm value. Debt ratio that is above the optimal point, the company value will decrease. This occurs because of the increasing use of debt affects the conflict of interest between creditors and owners. Creditors and company owners experience a greater potential for losses. That the increase in debt, the benefits of the debt no longer cover these costs. So the company's investment decision no longer considers the risk of its debt because the company does not dare to take a bigger risk by increasing debt. The event of financial distress, could occur with or without the presence of financial leverage effect[16]. This can be caused by other considerations such asreducing investment and reducing dividends are associated with recovery for all firms [11]. Another thing that can be considered by managers for investment decisions is investment opportunities. Investment opportunities are opportunities to realize more benefits through investment. Investment opportunity choices (IOS) are expected to produce greater returns in the future indicated by a positive NPV. The managers of financial distress will take advantage of these investment opportunities with the right considerations and calculations. This is closely related to the condition of the company whether it can recover or suffer more and more losses. The results of this study support [6] research that there is no effect of leverage on investment decisions. The absence of leverage indicates that the company does not react or does not pay special attention as a consideration for making investment decisions. Companies that experiencing financial distress do not have the courage to increase the company's risk by increasing debt as a source of funds for investment.

3. The third hypothesis (H3) states that profitability has a positive effect on investment decisions for companies experiencing financial distress. Obtained a significance value of 0.000 . The significance value of $0.000<0.05$ indicates that profitability affects investment decisions, so the third hypothesis is accepted (accept H3). The results of this test imply that the size of the company's profitability has a significant effect on the investment decisions of companies experiencing financial distress. Companies that experience financial distress in this study have low profitability. Based on the pecking order theory, funds that are considered cheap are internal funds rather than external funds because the company does not have any liability for issuance costs. One of the internal funds is the availability of net profit or profit. The performance or productivity of the company's assets is not maximized in obtaining a profit or profit. Low profit owned by the company means that there is little cash availability, low investment opportunities. This has an effect on the low investment decisions made by managers for the company. Financial distress companies will not invest if the funds to invest are not available. The company will also not take a bigger risk because the company's condition is in financial difficulty so that the financial distress company does not have the option to invest. It is also explained in the descriptive statistical test of this study that the sample companies have low investment decisions. The results of this study support the research of [9], [10] that there is an effect of profitability on investment decisions. The impact of profitability indicates that the company reacts or pays special attention as a consideration for making investment decisions.

\section{CONCLUSION}

This study was conducted to determine the effect of cash flow, leverage, and profitability on investment decisions in financial distress companies. The results of this study include cash flow that does not significantly affect investment decisions in companies experiencing financial distress. Leverage does not significantly affect investment decisions in companies experiencing financial distress. Profitability has a significant positive effect on investment decisions in companies experiencing financial distress.

\section{REFERENCES}

[1] L.G. Carlos, S.A. Sergio, and T.O. Begona, "Investment Decisions Of Companies In Financial Distress”, Bbq Business Research, 18, 174187, 2015.

[2] A. Ali, Z. Fan and N. Li, "The Role of Capital Expenditure Forecasts in Debt Contracting", SSRN, G31; M4, 2020.

[3] L. Michalkova, K. Valaskova, and K.F. Michalikova, "The Holistic View of the Symptoms of Financial Health of Businesses", Advances in Economics, Business and Management Research, 56, 90-94, 2018.

[4] M. J. Schill, "The Profitability Index", Darden Case, UVA-F-1945, 2020.

[5] Z. Serrasqueiro, and A. Caetano, "Trade-Off Theory Versus Pecking Order Theory : Capital Structure Decisions In A Peripheral Region Of Portugal", Journal of Business Economics and Management, 16 (2), 445-466, 2015.

[6] M. Zaki, "Pengaruh Arus Kas, Profitabilitas, Leverage, Dan Modal Kerja Terhadap Keputusan Investasi Aktiva Tetap Pada Perusahaan Financially Constrained”, Jurnal Ilmu Manajemen, 1(1), 2013.

[7] E. R. Bria, N. P. Y. Mendra, and I. P. E. Arizona, "Pengaruh Laporan Arus Kas Operasi Dan Laba Terhadap Keputusan Investasi", Kumpulan Hasil Riset Mahasiswa Akuntansi (Kharisma), 1(1), 2019.

[8] S.Bahri, "Pengaruh Free Cash Flow, Laba Bersih, Dan Ukuran Perusahaan Terhadap Keputusan Investasi (Studi Empiris Pada Perusahaan Manufaktur Sub Sektor Makanan Dan Minuman Yang Terdaftar di BEI)", Jurnal Peta, 2(1), 31-49, 2017.

[9] I. D. M. Endiana, "Analisis Faktor-Faktor Yang Berpengaruh Terhadap Keputusan Investasi Dengan Growth Opportunity Sebagai Moderating Variabel", Jurnal Manajemen \& Akuntansi, 22(01), 1-16, 2016.

[10] Rahmiati, and P. N. Huda, "Pengaruh Kebijakan Dividen, Profitabilitas, Dan Profitabilitas Terhadap Keputusan Investasi", Jurnal Kajian Manajemen Bisnis, 4(2 September), 2015.

[11] S. K. Koh, R. B. Durand, L. Dai, and M. Chang, "Financial Distress : Lifecycle and Corporate Restructing", 33, 19-33, 2015.

[12] S. S. Azofra, C. L. Gutierrez, and B. T. Olmo, "Covarage Of Financing Deficit In Firms In Financial Distress Under The Pecking Order Theory", Economie a Management, 19 (4), 104-116, 2016. 
[13] H. Waqas, and R. M. Rus, “ Predicting Financial Distress : Importance Of Accounting and Firm-Spesific Market Variables For Pakistan's Listed Firms", Cogent Economics \& Finance, 6: 1545739, 2018.

[14] E. I. Altman, and E. Hotchkiss, "Coporate Financial Distress and Backrupty", Third Edition, Canada : John Wiley \& Sons, Inc, 239, 2006.

[15] Marwan, Asri, “Keuangan Keperilakuan”, Yogyakarta: Bpfe, 2015.

[16] J. Carmassi and A. Patti, "Financial Distress and Bankruptcy : Tools for Preserving The Soundness of Financial System", 2014.

[17] S. Gatti, "Project Finance in Theory and Practice", USA : Elsevier, 2008.

[18] M. Statman, "Behavioral Finance", Second Generation, CFA Institute Research Foundation, 2019. 